\title{
Genetic variation in Tanis was associated with elevating plasma triglyceride level in Chinese nondiabetic subjects
}

Ying Gao ${ }^{1 \dagger}$, Xiang Xie ${ }^{1 \dagger}$, Yi-Tong Ma ${ }^{1 *}$, Yi-Ning Yang ${ }^{1}$, Xiao-Mei Li', Zhen-Yan Fu', Ying-Ying Zheng ${ }^{1}$, Xiang Ma ${ }^{1}$, Bang-Dang Chen ${ }^{2}$, Fen Liu' ${ }^{1}$ and Ying Huang ${ }^{1}$

\begin{abstract}
Background: The association of genetic polymorphisms of Tanis with triglyceride concentration in human has not been thoroughly examined. We aimed to investigate the relationship between triglyceride concentrations and Tanis genetic polymorphisms.

Methods: All participants ( $n=1497$ ) selected from subjects participating in the Cardiovascular Risk Survey (CRS) study were divided into two groups according to ethnicity (Han: $n=1059$; Uygur: $n=438$ ). Four tagging SNPs (rs12910524, rs1384565, rs2101171, rs4965814) of Tanis gene were genotyped using TaqMan ${ }^{\circledR}$ assays from Applied Biosystems following the manufacturer's suggestions and analyzed in an ABI 7900HT Fast Real-Time PCR System.

Results: We found that the SNP rs12910524 was associated with triglyceride levels by analyses of a dominant model $(P<0.001)$, recessive model $(P<0.001)$ and additive model $(P<0.001)$ not only in Han ethnic but also in Uygur ethnic group, and the difference remained significant after the adjustment of sex, age, alcohol intake, smoking, BMI and plasma glucose (GLU) level (All $P<0.001)$. However, this relationship was not observed in rs 1384565, rs2101171, and rs4965814 before and after multivariate adjustment (All $P>0.05$ ). Furthermore, there were significant interactions between rs 12910524 and $\mathrm{GLU}$ on TG both in Han ( $\mathrm{P}=0.001)$ and Uygur population $\left(P=2.60 \times 10^{-4}\right)$.
\end{abstract}

Conclusion: Our results indicated that the rs12910524 in the Tanis gene was associated with triglyceride concentrations in subjects without diabetes in China.

Keywords: Genetics, Tanis, Triglyceride, Diabetes, Polymorphisms

\section{Background}

Elevating triglycerides (TG) level, an essential component of the metabolic syndrome, is independently associated with coronary artery disease (CAD) [1]. High levels of fasting plasma TG are caused by not only environmental factors such as smoking[2-4], high-fat diet and alcohol intake [5,6], but also genetic factors including single nucleotide polymorphisms (SNPs). However, till date, only several candidate genes involving lipid metabolism [7-10] and CAD [11-14] have been discovered, and these genes

\footnotetext{
* Correspondence: myt-xj@163.com

${ }^{\dagger}$ Equal contributors

'Department of Cardiology, First Affiliated Hospital of Xinjiang Medical University, Urumqi 830011, P.R. China Full list of author information is available at the end of the article
}

only explain a small fraction of the total interindividual variation in plasma TG levels [15-17].

Tanis, a novel discovered membrane protein, has been suggested to be involved in the development of diabetes and dyslipidemia $[18,19]$. In a polygenic animal model of type 2 diabetes model-Psammomys obesus, the Tanis was found to be positively correlated to circulating TG concentrations [19]. However, the association of genetic polymorphisms of Tanis with plasma TG concentration in humans has not been thoroughly examined. In addition, Tanis was identified as a newly found receptor of amyloid A-1 (SAA1), which is not only an inflammatory marker but also an apolipoprotein [20]. In the previous study $[20,21]$, we found that SAA1 gene polymorphisms were associated with dyslipidemia in Chinese subjects. Tanis, as
C Biomed Central 
a receptor of SAA1, also called SELS, located on chromosome15q26.3, encodes selenoprotein $S$ which participates in the retro-translocation of misfolded proteins from the endoplasmic reticulum (ER) to the cytosol for their degradation [22]. Several previous studies indicated that the variations in Tanis gene were associated with proinflammatory cytokines such as interleukin (IL)-6, IL-1 $\beta$ and TNF- $\alpha$ [23] and cardiovascular disease [24] and metabolic factors [25]. However, the relationships between Tanis gene and lipid profile have not been thoroughly investigated. Xinjiang is part of the ancient Silk Road and borders eight countries including Russia, Kazakhstan, Kirghizastan, Tajikistan, Pakistan, Mongolia, India, and Afghanistan. There are more than 13 ethnic groups living in this area. Among them, the Uygur people account for $46 \%$, and Han account for $40 \%$. In this study, we aimed to observe the associations of tagging SNPs in Tanis gene with fasting plasma TG levels in Chinese Han and Uygur population in Xinjiang, the western China.

\section{Results and discussion}

This study consists of two ethnic groups (Han: $n=1059$; Uygur: $n=438$ ). The clinical and metabolic characteristics of the study population are shown separately for Han and Uygur in Table 1.

All genotyped SNPs were in Hardy-Weinberg equilibrium (all $P>0.05$, data not shown). Table 2 shows detailed information for each SNP as well as the allele frequencies.

Table 1 Demographic and risk profile of the study population

\begin{tabular}{|c|c|c|c|}
\hline \multirow[t]{2}{*}{ Risk factors } & \multicolumn{2}{|c|}{ No. (\%) or Mean \pm SD } & \multirow{2}{*}{$\begin{array}{c}\mathrm{P} \\
\text { values }\end{array}$} \\
\hline & Han $(n=1059)$ & Uygur $(n=438)$ & \\
\hline Age (years) & $60.38 \pm 11.81$ & $63.16 \pm 10.70$ & $<0.001$ \\
\hline Female (\%) & $481(45.4)$ & $174(39.7)$ & 0.043 \\
\hline Never drink (\%) & $837(79.0)$ & $393(89.7)$ & $<0.001$ \\
\hline Former drinker (\%) & 201(19.0) & $24(5.5)$ & \\
\hline Current drinker (\%) & $21(2.0)$ & $21(4.8)$ & \\
\hline Never smoking (\%) & $689(65.1)$ & $331(75.6)$ & $<0.001$ \\
\hline Former smoking (\%) & $298(28.1)$ & $72(16.4)$ & \\
\hline Current smoking (\%) & $72(6.8)$ & $35(8.0)$ & \\
\hline $\mathrm{BMI}\left(\mathrm{Kg} / \mathrm{m}^{2}\right)$ & $24.52 \pm 3.40$ & $24.99 \pm 3.99$ & 0.020 \\
\hline $\mathrm{SBP}(\mathrm{mmHg})$ & $122.21 \pm 13.11$ & $120.64 \pm 10.07$ & 0.025 \\
\hline $\mathrm{DBP}(\mathrm{mmHg})$ & $76.75 \pm 10.66$ & $73.46 \pm 7.40$ & $<0.001$ \\
\hline GLU (mmol/L) & $4.57 \pm 0.86$ & $4.30 \pm 0.45$ & $<0.001$ \\
\hline $\mathrm{TG}(\mathrm{mmol} / \mathrm{L})$ & $0.96 \pm 0.34$ & $0.93 \pm 0.35$ & 0.080 \\
\hline $\mathrm{TC}(\mathrm{mmol} / \mathrm{L})$ & $4.26 \pm 0.98$ & $4.12 \pm 0.94$ & 0.015 \\
\hline $\mathrm{HDL}(\mathrm{mmol} / \mathrm{L})$ & $1.28 \pm 0.44$ & $1.27 \pm 0.47$ & 0.172 \\
\hline $\mathrm{LDL}-\mathrm{C}(\mathrm{mmol} / \mathrm{L})$ & $2.65 \pm 0.81$ & $2.54 \pm 0.80$ & 0.016 \\
\hline
\end{tabular}

Note: $H D L$ high-density lipoprotein, $L D L$ low-density lipoprotein, SBP Systolic blood pressure, DBP Diastolic blood pressure, TG Triglycerides, TC Cholesterol, $B M I$ Body mass index, GLU Glucose.
Table 2 Distributions of SNPs of Tanis gene in Han and Uygur population

\begin{tabular}{|c|c|c|c|c|}
\hline \multirow[t]{2}{*}{ SNPs } & \multirow[t]{2}{*}{ Genotypes } & \multicolumn{2}{|c|}{ Ethnic } & \multirow{2}{*}{$\begin{array}{c}P \\
\text { value }\end{array}$} \\
\hline & & Han, n (\%) & Uygur, n (\%) & \\
\hline \multirow[t]{3}{*}{ rs12910524 } & $\pi$ & $158(14.9)$ & $62(14.2)$ & 0.406 \\
\hline & TC & $486(45.9)$ & $188(42.9)$ & \\
\hline & CC & $415(39.2)$ & $188(42.9)$ & \\
\hline \multirow[t]{3}{*}{ rs1384565 } & $\mathrm{CC}$ & $74(7.0)$ & $11(2.5)$ & $<0.001$ \\
\hline & CT & $442(41.7)$ & $102(23.3)$ & \\
\hline & $\pi$ & $543(51.3)$ & $325(74.2)$ & \\
\hline \multirow[t]{3}{*}{ rs2101171 } & CC & $30(2.8)$ & $10(2.3)$ & $<0.001$ \\
\hline & CT & $320(30.2)$ & $109(24.9)$ & \\
\hline & $\pi$ & 709 (66.9) & $319(72.8)$ & \\
\hline \multirow[t]{3}{*}{ rs4965814 } & CC & $182(17.2)$ & $68(15.5)$ & 0.034 \\
\hline & CT & $517(48.8)$ & $190(43.4)$ & \\
\hline & $\pi$ & $360(34.0)$ & $180(41.1)$ & \\
\hline
\end{tabular}

Both in Chinese Han and Uygur populations, we found that the rs12910524 was significantly associated with plasma TG levels in a dominant model, additive model, or recessive model before (All $\mathrm{P}<0.001$ ) and after multivariate adjustment (All $\mathrm{P}<0.001$; Table 3 ). However, these associations were not found in rs1384565, rs2101171, and rs4965814 before and after adjustment of confounders. Furthermore, using the general linear model analysis, we found that the GLU level was significantly associated with TG level both in Han $(\mathrm{P}=0.001)$ and Uygur populations $\left(\mathrm{P}=2.99 \times 10^{-6}\right)$. And, we also found significant interactions between rs12910524 and GLU on plasma TG both in Han $\left(\mathrm{P}=0.012\right.$; Table 4) and Uygur populations $\left(\mathrm{P}=2.60 \times 10^{-4}\right.$; Table 5). However, we did not find any interaction between rs1384565, rs2101171, and rs4965814 and GLU level (Table 4, Table 5).

In Chinese Uygur population, we found that the rs12910524 was significantly associated with plasma TC levels in a dominant model, additive model, or recessive model before (All $\mathrm{P}<0.01$ ) and after multivariate adjustment (All P <0.01; Table 6). And we also found that the rs12910524 was significantly associated with plasma LDL-C level in a recessive model and an additive model before (All $\mathrm{P}<0.01$ ) and after multivariate adjustment (All $\mathrm{P}<0.01$; Table 7). In addition, we found the rs1384565 was significantly associated with plasma HDL-C level in a dominant model and in an additive model after multivariate adjustment (both $\mathrm{P}<0.01$; Table 8 ). However, we did not find any association of Tanis genetic polymorphisms with plasma TC, HDL-C, and LDL-C levels in Chinese Han population.

In this study, we observed that variation in the Tanis gene was associated with plasma TG levels in Chinese subjects. Individuals with the C allele of rs12910524 had significantly higher plasma TG levels when compared with TT genotype carriers. To our knowledge, this is the 
Table 3 Association of Tanis SNPs with log-transformed TG value in Han and Uygur population

\begin{tabular}{|c|c|c|c|c|c|c|c|c|c|c|}
\hline & \multirow[b]{2}{*}{ Wild/rare allele } & \multicolumn{3}{|c|}{ Mean log-transformed TG level } & \multicolumn{3}{|c|}{ Model 1‡ } & \multicolumn{3}{|c|}{ Model $2 \S$} \\
\hline & & $\begin{array}{l}\text { Homozygous for } \\
\text { rare allele }\end{array}$ & Heterozygous & $\begin{array}{c}\text { Homozygous for } \\
\text { wild allele }\end{array}$ & $P \operatorname{Rec}^{*}$ & P Domt & P Add ${ }^{*}$ & $P \operatorname{Rec}^{*}$ & P Domt & P Add $*$ \\
\hline \multicolumn{11}{|l|}{ Han } \\
\hline rs12910524 & $\mathrm{C} / \mathrm{T}$ & $-0.32 \pm 0.45$ & $-0.11 \pm 0.39$ & $-0.02 \pm 0.33$ & $<0.001$ & $<0.001$ & $<0.001$ & $<0.001$ & $<0.001$ & $<0.001$ \\
\hline rs1384565 & $\mathrm{T} / \mathrm{C}$ & $-0.11 \pm 0.46$ & $-0.12 \pm 0.38$ & $-0.98 \pm 0.39$ & 0.337 & 0.955 & 0.595 & 0.222 & 0.967 & 0.452 \\
\hline rs2101171 & $\mathrm{T} / \mathrm{C}$ & $-0.26 \pm 0.41$ & $-0.09 \pm 0.40$ & $-0.11 \pm 0.38$ & 0.902 & 0.038 & 0.094 & 0.864 & 0.019 & 0.048 \\
\hline rs4965814 & $\mathrm{T} / \mathrm{C}$ & $-0.09 \pm 0.41$ & $-0.12 \pm 0.38$ & $-0.10 \pm 0.39$ & 0.649 & 0.585 & 0.688 & 0.509 & 0.492 & 0.510 \\
\hline \multicolumn{11}{|l|}{ Uygur } \\
\hline rs12910524 & $\mathrm{C} / \mathrm{T}$ & $-0.50 \pm 0.49$ & $-0.15 \pm 0.41$ & $-0.05 \pm 0.32$ & $<0.001$ & $<0.001$ & $<0.001$ & $<0.001$ & $<0.001$ & $<0.001$ \\
\hline rs1384565 & $\mathrm{T} / \mathrm{C}$ & $-0.30 \pm 0.53$ & $-0.16 \pm 0.45$ & $-0.15 \pm 0.40$ & 0.547 & 0.233 & 0.471 & 0.485 & 0.212 & 0.431 \\
\hline rs2101171 & $\mathrm{T} / \mathrm{C}$ & $-0.17 \pm 0.41$ & $-0.12 \pm 0.42$ & $-0.14 \pm 0.47$ & 0.928 & 0.272 & 0.537 & 0.778 & 0.295 & 0.494 \\
\hline rs4965814 & $\mathrm{T} / \mathrm{C}$ & $-0.23 \pm 0.43$ & $-0.15 \pm 0.43$ & $-0.13 \pm 0.39$ & 0.351 & 0.097 & 0.237 & 0.366 & 0.066 & 0.179 \\
\hline
\end{tabular}

§Analysis of covariance adjusted for sex, age, smoking, alcohol drinking, and GLU; łUnadjusted model; *recessive model; †dominant model; *additive model.

first study to investigate the common allelic variant in Tanis gene and its association with plasma TG levels.

The human Tanis gene is located at 15q26.3. Although this region has not been previously identified in genomewide linkage scans for diabetes-related phenotypes in human populations, previous studies [25] indicated that the Tanis gene expression was positively correlated to BMI, plasma levels of TG and HDL cholesterol, insulin, and blood glucose levels. Also, several studies suggested that the variations in Tanis gene were associated with inflammation [23], coronary heart disease (CHD) and ischemic stroke [24], and metabolic disease [25].

The plasma triglyceride level is known to be influenced by a large number of factors, including age, sex, hypertension, diabetes, smoking and alcohol intake. Our

Table 4 Interactions between SNPs of Tanis and GLU on TG levels in Chinese Han population

\begin{tabular}{lccccc}
\hline Source & $\begin{array}{c}\text { Type III sum } \\
\text { of squares }\end{array}$ & df & $\begin{array}{c}\text { Mean } \\
\text { square }\end{array}$ & F & Sig. \\
\hline Corrected model & $15.139^{\mathrm{a}}$ & 13 & 1.165 & 8.322 & $3.50 \times 10^{-16}$ \\
\hline Age & 0.051 & 1 & 0.051 & 0.365 & 0.546 \\
\hline Sex & 0.030 & 1 & 0.030 & 0.216 & 0.642 \\
\hline Smoking & 0.012 & 1 & 0.012 & 0.085 & 0.771 \\
\hline Drinking & 0.117 & 1 & 0.117 & 0.838 & 0.360 \\
\hline BMl & 0.028 & 1 & 0.028 & 0.202 & 0.653 \\
\hline rs12910524 & 2.036 & 2 & 1.018 & 7.273 & $\mathbf{0 . 0 0 1}$ \\
\hline GLU * rs12910524 & 0.933 & 3 & 0.311 & 2.222 & $\mathbf{0 . 0 1 2}$ \\
\hline GLU * rs4965814 & 0.283 & 1 & 0.283 & 2.021 & 0.155 \\
\hline GLU * rs2101171 & 0.232 & 1 & 0.232 & 1.658 & 0.198 \\
\hline GLU * rs1384565 & 0.312 & 1 & 0.312 & 2.227 & 0.136 \\
\hline Error & 146.240 & 1045 & 0.140 & & \\
\hline Total & 173.988 & 1059 & & & \\
\hline Corrected total & 161.380 & 1058 & & & \\
\hline
\end{tabular}

${ }^{\mathrm{a}}$ Squared $=0.094$ (Adjusted R Squared $=0.083$ ). findings show that rs1291054 is an independent determinant of triglyceride level, and does not influence the level by modulating some confounding factors such age, sex, smoking, BMI, and alcohol intake. Walder et al. [19] described the biological characteristics of Tanis first. In their study, they found that Tanis gene expression was increased 2.2-fold after a 24-h fast in P. obesus, a polygenic animal model of type 2 diabetes and metabolic syndrome. Also, they found that there was a positive correlation between Tanis expression and circulating TG concentrations (Pearson $\mathrm{r}=0.593, \mathrm{P}=0.007$ ); as well as blood glucose (Spearman $\mathrm{r}=0.378, \mathrm{P}=0.010$ ) and insulin concentrations (Spearman $\mathrm{r}=0.416, \mathrm{P}=0.004$ ). However, subsequently multiple linear regression analysis indicated that only the change in blood glucose concentration was

Table 5 Interactions between SNPs of Tanis and GLU on TG levels in Chinese Uygur population

\begin{tabular}{lccccc}
\hline Source & $\begin{array}{c}\text { Type III sum } \\
\text { of squares }\end{array}$ & df & $\begin{array}{c}\text { Mean } \\
\text { square }\end{array}$ & $\mathbf{F}$ & P value \\
\hline Corrected model & $16.946^{a}$ & 13 & 1.304 & 9.513 & $1.97 \times 10^{-17}$ \\
\hline Age & 0.132 & 1 & 0.132 & 0.965 & 0.326 \\
\hline sex & 0.011 & 1 & 0.011 & 0.079 & 0.779 \\
\hline Smoking & 0.001 & 1 & 0.001 & 0.010 & 0.920 \\
\hline Drinking & 0.240 & 1 & 0.240 & 1.748 & 0.187 \\
\hline BMI & 0.419 & 1 & 0.419 & 3.061 & 0.081 \\
\hline rs12910524 & 3.593 & 2 & 1.796 & 13.109 & $\mathbf{2 . 9 9 \times 1 0 ^ { - 6 }}$ \\
\hline GLU * rs12910524 & 2.675 & 3 & 0.892 & 6.507 & $\mathbf{2 . 6 0 \times 1 0 ^ { - 4 }}$ \\
\hline GLU * rs4965814 & 0.360 & 1 & 0.360 & 2.630 & 0.106 \\
\hline GLU * rs2101171 & 0.148 & 1 & 0.148 & 1.083 & 0.299 \\
\hline GLU * rs1384565 & 0.147 & 1 & 0.147 & 1.074 & 0.301 \\
\hline Error & 58.103 & 424 & 0.137 & & \\
\hline Total & 85.395 & 438 & & & \\
\hline Corrected total & 75.049 & 437 & & & \\
\hline
\end{tabular}

${ }^{\mathrm{a}} \mathrm{R}$ Squared $=0.226$ (Adjusted R Squared $=0.202$ ). 
Table 6 Association of Tanis SNPs with TC in Han and Uygur population

\begin{tabular}{|c|c|c|c|c|c|c|c|c|c|c|}
\hline & \multirow[b]{2}{*}{$\begin{array}{l}\text { Wild/Rare } \\
\text { allele }\end{array}$} & \multicolumn{3}{|c|}{ Mean TC level } & \multicolumn{3}{|c|}{ Model 1f } & \multicolumn{3}{|c|}{ Model $2 \S$} \\
\hline & & $\begin{array}{c}\text { Homozygous for } \\
\text { rare allele }\end{array}$ & Heterozygous & $\begin{array}{c}\text { Homozygous for } \\
\text { wild allele }\end{array}$ & $P \operatorname{Rec}^{*}$ & P Dom + & P Add ${ }^{\star}$ & $P \operatorname{Rec}^{*}$ & P Dom & P Add ${ }^{*}$ \\
\hline \multicolumn{11}{|l|}{ Han } \\
\hline rs12910524 & $\mathrm{C} / \mathrm{T}$ & $4.11 \pm 1.13$ & $4.24 \pm 0.95$ & $4.34 \pm 0.92$ & 0.047 & 0.034 & 0.042 & 0.062 & 0.107 & 0.10 \\
\hline rs1384565 & $\mathrm{T} / \mathrm{C}$ & $4.26 \pm 1.01$ & $4.30 \pm 0.99$ & $4.22 \pm 0.99$ & 0.265 & 0.998 & 0.510 & 0.493 & 0.761 & 0.692 \\
\hline rs2101171 & $\mathrm{T} / \mathrm{C}$ & $4.09 \pm 1.01$ & $4.24 \pm 0.95$ & $4.26 \pm 0.97$ & 0.479 & 0.330 & 0.553 & 0.529 & 0.142 & 0.328 \\
\hline rs4965814 & $\mathrm{T} / \mathrm{C}$ & $4.17 \pm 1.03$ & $4.29 \pm 0.98$ & $4.26 \pm 0.92$ & 0.955 & 0.184 & 0.362 & 0.757 & 0.274 & 0.549 \\
\hline \multicolumn{11}{|l|}{ Uygur } \\
\hline rs12910524 & $\mathrm{C} / \mathrm{T}$ & $3.62 \pm 0.99$ & $4.13 \pm 0.93$ & $4.28 \pm 0.89$ & $<0.001$ & 0.003 & $<0.001$ & $<0.001$ & 0.005 & $<0.001$ \\
\hline rs1384565 & $\mathrm{T} / \mathrm{C}$ & $3.59 \pm 1.19$ & $4.15 \pm 0.93$ & $4.13 \pm 0.94$ & 0.731 & 0.058 & 0.163 & 0.655 & 0.079 & 0.213 \\
\hline rs2101171 & $\mathrm{T} / \mathrm{C}$ & $4.13 \pm 0.94$ & $4.06 \pm 0.94$ & $4.38 \pm 1.05$ & 0.391 & 0.622 & 0.530 & 0.498 & 0.535 & 0.570 \\
\hline rs4965814 & $\mathrm{T} / \mathrm{C}$ & $4.08 \pm 1.03$ & $4.09 \pm 0.97$ & $4.18 \pm 0.88$ & 0.310 & 0.689 & 0.597 & 0.361 & 0.526 & 0.625 \\
\hline
\end{tabular}

§Analysis of covariance adjusted for sex, age, smoking, alcohol drinking, and GLU; łUnadjusted model; *recessive model; tdominant model; *additive model.

independently associated with Tanis gene expression. This result suggests that the association of Tanis gene expression with TG level can be modified by blood glucose level. Therefore, in this study, we excluded the diabetic patients when we selected participants at the beginning of the study, and we found that in nondiabetic subjects, the rs12910524 was independently associated with plasma TG level, and this relationship was not modified by the fasting blood glucose level. And this association was observed not only in Chinese Han but also in Chinese Uygur population. We also analyzed the associations of Tanis genetic polymorphisms with plasma TC, HDL-C, and LDL-C levels. In Chinese Uygur population, we found that the rs12910524 was significantly associated with plasma TC levels and plasma LDL-C levels. And, we also found that the rs1384565 was significantly associated with plasma HDL-C levels. However, we did not find any association of Tanis genetic polymorphisms with plasma TC, HDL-C, and LDL-C levels in Chinese Han population. This discrepancy may be explained by the different distributions of Tanis genetic polymorphisms and some confounders between Chinese Han and Uygur population.

In addition, some published data indicated that inflammatory genes may regulate fasting TG levels [26]. And previous studies also indicated that Tanis gene was associated with inflammatory cytokines [23]. In the present study, we found Tanis genetic polymorphism was associated with TG level. However we have no evidences to demonstrate whether this association was related to inflammation because of the absence of some inflammatory cytokines parameters. Otherwise, because of the absence of some confounders such as plasma HOMA-IR or HbA1c levels, eating habits, working pressure and the social disparities in our database, we did not include these variables in the multivariate analysis. This fact is a limitation of our study.

Table 7 Association of Tanis SNPs with LDL-C in Han and Uygur population

\begin{tabular}{|c|c|c|c|c|c|c|c|c|c|c|}
\hline & \multirow[b]{2}{*}{$\begin{array}{l}\text { Wild/Rare } \\
\text { allele }\end{array}$} & \multicolumn{3}{|c|}{ Mean LDL-C level } & \multicolumn{3}{|c|}{ Model 1‡ } & \multicolumn{3}{|c|}{ Model $2 \S$} \\
\hline & & $\begin{array}{l}\text { Homozygous for } \\
\text { rare allele }\end{array}$ & Heterozygous & $\begin{array}{l}\text { Homozygous for } \\
\text { wild allele }\end{array}$ & $P \operatorname{Rec}^{*}$ & P Domt & P Add ${ }^{*}$ & $P \operatorname{Rec}^{*}$ & P Domt & P Add * \\
\hline \multicolumn{11}{|l|}{ Han } \\
\hline rs12910524 & $C / T$ & $2.55 \pm 0.93$ & $2.61 \pm 0.79$ & $2.72 \pm 0.77$ & 0.091 & 0.014 & 0.032 & 0.126 & 0.034 & 0.071 \\
\hline rs1384565 & $\mathrm{T} / \mathrm{C}$ & $2.71 \pm 0.90$ & $2.70 \pm 0.82$ & $2.60 \pm 0.78$ & 0.043 & 0.502 & 0.128 & 0.119 & 0.731 & 0.295 \\
\hline rs2101171 & $\mathrm{T} / \mathrm{C}$ & $2.38 \pm 0.80$ & $2.60 \pm 0.74$ & $2.68 \pm 0.83$ & 0.051 & 0.069 & 0.057 & 0.052 & 0.036 & 0.037 \\
\hline rs4965814 & $\mathrm{T} / \mathrm{C}$ & $2.55 \pm 0.84$ & $2.68 \pm 0.82$ & $2.65 \pm 0.77$ & 0.970 & 0.070 & 0.163 & 0.869 & 0.151 & 0.339 \\
\hline \multicolumn{11}{|l|}{ Uygur } \\
\hline rs12910524 & $\mathrm{C} / \mathrm{T}$ & $2.25 \pm 0.80$ & $2.52 \pm 0.81$ & $2.64 \pm 0.78$ & 0.003 & 0.022 & 0.004 & 0.005 & 0.025 & 0.007 \\
\hline rs1384565 & $\mathrm{T} / \mathrm{C}$ & $2.02 \pm 0.84$ & $2.52 \pm 0.78$ & $2.56 \pm 0.81$ & 0.312 & 0.032 & 0.091 & 0.323 & 0.036 & 0.102 \\
\hline rs2101171 & $\mathrm{T} / \mathrm{C}$ & $2.54 \pm 0.79$ & $2.53 \pm 0.86$ & $2.57 \pm 0.80$ & 0.905 & 0.951 & 0.988 & 0.888 & 0.945 & 0.990 \\
\hline rs4965814 & $\mathrm{T} / \mathrm{C}$ & $2.40 \pm 0.47$ & $2.55 \pm 0.82$ & $2.58 \pm 0.80$ & 0.395 & 0.117 & 0.280 & 0.447 & 0.106 & 0.267 \\
\hline
\end{tabular}

§Analysis of covariance adjusted for sex, age, smoking, alcohol drinking, and GLU; fUnadjusted model; * ${ }^{*}$ ecessive model; tdominant model; *additive model. 
Table 8 Association of Tanis SNPs with HDL-C in Han and Uygur population

\begin{tabular}{|c|c|c|c|c|c|c|c|c|c|c|}
\hline & \multirow[b]{2}{*}{ Wild/Rare allele } & \multicolumn{3}{|c|}{ Mean HDL-C level } & \multicolumn{3}{|c|}{ Model 1f } & \multicolumn{3}{|c|}{ Model $2 \S$} \\
\hline & & $\begin{array}{c}\text { Homozygous for } \\
\text { rare allele }\end{array}$ & Heterozygous & $\begin{array}{c}\text { Homozygous for } \\
\text { wild allele }\end{array}$ & $P \operatorname{Rec}^{*}$ & P Domt & P Add* & $P \operatorname{Rec}^{*}$ & P Domt & P Add ${ }^{*}$ \\
\hline \multicolumn{11}{|l|}{ Han } \\
\hline rs12910524 & $\mathrm{C} / \mathrm{T}$ & $1.28 \pm 0.41$ & $1.32 \pm 0.44$ & $1.30 \pm 0.46$ & 0.428 & 0.607 & 0.518 & 0.505 & 0.388 & 0.414 \\
\hline rs1384565 & $\mathrm{T} / \mathrm{C}$ & $1.32 \pm 0.54$ & $1.31 \pm 0.45$ & $1.30 \pm 0.42$ & 0.499 & 0.772 & 0.792 & 0.516 & 0.682 & 0.787 \\
\hline rs2101171 & $\mathrm{T} / \mathrm{C}$ & $1.27 \pm 0.52$ & $1.31 \pm 0.44$ & $1.31 \pm 0.44$ & 0.996 & 0.673 & 0.910 & 0.974 & 0.470 & 0.752 \\
\hline rs4965814 & $\mathrm{T} / \mathrm{C}$ & $1.27 \pm 0.47$ & $1.31 \pm 0.44$ & $1.32 \pm 0.43$ & 0.442 & 0.215 & 0.430 & 0.289 & 0.186 & 0.335 \\
\hline \multicolumn{11}{|l|}{ Uygur } \\
\hline rs12910524 & $\mathrm{C} / \mathrm{T}$ & $1.19 \pm 0.42$ & $1.24 \pm 0.40$ & $1.33 \pm 0.54$ & 0.127 & 0.025 & 0.059 & 0.285 & 0.065 & 0.062 \\
\hline rs1384565 & $\mathrm{T} / \mathrm{C}$ & $1.64 \pm 1.72$ & $1.31 \pm 0.34$ & $1.25 \pm 0.40$ & 0.073 & 0.007 & 0.014 & 0.103 & 0.002 & 0.007 \\
\hline rs2101171 & $\mathrm{T} / \mathrm{C}$ & $1.28 \pm 0.50$ & $1.22 \pm 0.35$ & $1.51 \pm 0.51$ & 0.096 & 0.498 & 0.131 & 0.341 & 0.347 & 0.126 \\
\hline rs4965814 & $\mathrm{T} / \mathrm{C}$ & $1.39 \pm 0.77$ & $1.25 \pm 0.38$ & $1.25 \pm 0.39$ & 0.413 & 0.025 & 0.082 & 0.424 & 0.047 & 0.193 \\
\hline
\end{tabular}

§Analysis of covariance adjusted for sex, age, smoking, alcohol drinking, and GLU; łUnadjusted model; *recessive model; tdominant model; *additive model.

\section{Conclusions}

In conclusion, our results indicate that the Tanis gene rs12910524 polymorphism is an important and clinically relevant determinant of plasma TG levels in the Chinese subjects without diabetes.

\section{Subjects and methods Subjects}

This study was approved by the Ethics Committee of the First Affiliated Hospital of Xinjiang Medical University and was conducted according to the standards of the Declaration of Helsinki. Written informed consent was obtained from the participants. All the participants were selected from the Cardiovascular Risk Survey (CRS) study which was described in the previous studies $[27,28]$. From these subjects participating in CRS ( $n=14$ 618), we selected 1821 participants who were free from diabetes, hypertension, any history of CAD, or any history of taking lipid-lowering drugs. We defined diabetes by using the American Diabetes Association (ADA) 2009 criteria as described previously [29] (fasting plasma glucose $\geq 7.0 \mathrm{mmol} / \mathrm{L}[\geq 126 \mathrm{mg} / \mathrm{dL}]$ ) or self-reported current diabetes treatments in the survey. Among these 1821 participants, only 1740 (Han: $n=1251$; Uygur: $n=$ 489) participants consented to providing blood samples for DNA analysis. We excluded 243 hypertriglyceridemia (fasting plasma TG $\geq 1.7 \mathrm{mmol} / \mathrm{L}$ ) patients during the analysis. The analysis presented in this study was based on 1497 subjects (Han: $\mathrm{n}=1059$; Uygur: $\mathrm{n}=438$ ) who had passed the eligibility criteria and had complete data on Tanis genotype.

\section{Biological and lifestyle measurements}

Height, body weight, and blood pressure were measured as described previously $[27,28]$. Smoking and drinking status was self-reported by study questionnaire as described previously [27,28]. We measured the fasting plasma concentration of total cholesterol, triglyceride (TG), low-density lipoprotein (LDL), high-density lipoprotein (HDL) and glucose using an equipment for chemical analysis (Dimension AR/AVL Clinical Chemistry System, Newark, NJ) employed by the Clinical Laboratory Department of the First Affiliated Hospital of Xinjiang Medical University as described previously [27-31].

\section{Tanis single-nucleotide polymorphism genotyping}

There are 190 SNPs for the human Tanis gene listed in the National Center for Biotechnology Information SNP database (http://www.ncbi.nlm.nih.gov/ SNP).

We also screened the data for the Tag SNPs on the International HapMap Project website (http://www. hapmap.org/). Using the Haploview 4.2 software and the HapMap phrase II database, we obtained four tagging SNPs (rs12910524, rs1384565, rs2101171, and rs4965814) for Chinese Han using minor allele frequency (MAF) $\geq$ 0.05 and linkage disequilibrium patterns with $r^{2} \geq 0.8$ as a cutoff.

Genomic DNA was extracted from the peripheral blood leukocytes using a DNA extraction Kit (Beijing Bioteke Co. Ltd, China). Genotyping was confirmed using TaqMan ${ }^{\circ}$ assays from Applied Biosystems following the manufacturer's suggestions and analyzed in an ABI 7900HT Fast RealTime PCR System. To ensure the results to be verified, of the genotyped samples, $10 \%$ were duplicated and there was at least one positive and one negative control per 96-well DNA plate in our assays. The accuracy of the genotyping was determined by the genotype concordance between duplicate samples. We obtained a $100 \%$ concordance between the genotyped duplicate samples.

\section{Statistical analysis}

All analyses were carried out using SPSS version 17.0 (SPSS Inc., Chicago, IL, USA). The Hardy-Weinberg equilibrium was assessed using chi-square analysis. The 
characteristics of the study population were expressed as the mean \pm standard deviation or as a ratio. Fasting triglycerides were log-transformed using natural logarithms for analysis. General linear model analysis was undertaken to test for associations between SNP genotypes and TG levels after adjusting for confounding variables. Single-SNP effects with continuous variables were analyzed using linear regression using three models. These were the additive (common allele homozygotes coded as 1 , heterozygotes as 2 , and recessive allele homozygotes as 3 ); dominant (common allele homozygotes coded as 1 and heterozygotes and recessive allele homozygotesas 2); and recessive (common allele homozygotes and heterozygotes coded as 1 and recessive allele homozygotes as 2) models as described previously [16]. Normality was assessed by plotting the residuals. To assess the association of each SNP with TG level, we used a Bonferroni correction to control for the number of variants tested; this was 4 , so the probability value, 0.0125 , was considered to be significant.

\section{Abbreviations}

SNP: Single nucleotide polymorphisms; CAD: Coronary artery disease; SAA: Serum amyloid A; TG: Triglycerides; TC: Total cholesterol; HDL-C: Highdensity lipoprotein; LDL-C: Low-density lipoprotein.

\section{Competing interests}

The authors declare that they have no competing interests.

\section{Authors' contributions}

$Y G$ and $X X$ carried out the molecular genetic studies and drafted the manuscript.YNY, ZYF and XML carried out the genotyping. $X M, Y C$, and BDC participated in the design of the study and performed the statistical analysis. YTM, YH, FL and YYZ conceived of the study and participated in its design and coordination and helped to draft the manuscript. All authors read and approved the final manuscript.

\section{Acknowledgements}

This work has been supported financially by grants from the Natural Science Foundation of Xinjiang (2011211B32)

\section{Author details}

'Department of Cardiology, First Affiliated Hospital of Xinjiang Medical University, Urumqi 830011 , P.R. China. ${ }^{2}$ Xinjiang Key Laboratory of Cardiovascular Disease Research, Urumqi 830011, P.R. China.

Received: 16 May 2013 Accepted: 29 June 2013

Published: 5 July 2013

\section{References}

1. Cullen P: Evidence that triglycerides are an independent coronary heart disease risk factor. Am J Cardiol 2000, 86:943-949.1.

2. Park E, Kang MH: Smoking and high plasma triglyceride levels as risk factors for oxidative DNA damage in the Korean population. Ann Nutr Metab 2004, 48(1):36-36.

3. Sentí M, Elosua R, Tomás M, Sala J, Masiá R, Ordovás JM, et al: Physical activity modulates the combined effect of a common variant of the lipoprotein lipase gene and smoking on serumtriglyceride levels and high-density lipoprotein cholesterol in men. Hum Genet 2001, 109(4):385-392.

4. Waterworth DM, Talmud PJ, Bujac SR, Fisher RM, Miller GJ, Humphries SE: Contribution of apolipoprotein C-III gene variants to determination of triglyceride levels and interaction with smoking in middle-aged men. Arterioscler Thromb Vasc Biol 2000, 20(12):2663-2669.

5. Zhong W, Zhao Y, Tang Y, Wei X, Shi X, Sun W, et al: Chronic alcohol exposure stimulates adipose tissue lipolysis in mice: role of reverse triglyceride transport in the pathogenesis of alcoholic steatosis. Am J Pathol 2012, 180(3):998-1007.

6. Pieters M, de Lange Z, Hoekstra T, Ellis SM, Kruger A: Triglyceride concentration and waist circumference influence alcohol-related plasminog en activator inhibitor-1 activity increase in black South Africans. Blood Coagul Fibrinolysis 2010, 21(8):736-743.

7. Ivanova R, Puerta S, Garrido A, Cueto I, Ferro A, Ariza MJ, et al: ANGPTL4 variants $\mathrm{E} 40 \mathrm{~K}$ and $\mathrm{T} 266 \mathrm{M}$ are associated with lower fasting triglyceride levels in Non-Hispanic White Americans from the Look AHEAD Clinical Trial. Hepatobiliary Pancreat Dis Int 2012, 11(1):96-101.

8. Smart-Halajko MC, Kelley-Hedgepeth A, Montefusco MC, Cooper JA, Kopin A, McCaffrey JM, et al: Look AHEAD Study. BMC Med Genet 2011, 12:89.

9. Coassin S, Schweiger M, Kloss-Brandstätter A, Lamina C, Haun M, Erhart G, et al: Investigation and functional characterization of rare genetic variants in the adipose triglyceride lipase in a large healthy working population. PLoS Genet 2010, 6(12):e1001239.

10. Sáez ME, González-Pérez A, Martínez-Larrad MT, Gayán J, Real LM, Serrano-R íos M, et al: WWOX gene is associated with HDL cholesterol and triglyceride levels. BMC Med Genet 2010, 11:148.

11. Lv X, Zhang Y, Rao S, Qiu J, Wang M, Luo X, Zuo X, Su D, Feng X, Yang Y, Ouyang P, Chen Y, Li X, Xiao Y, Ling W: Joint effects of genetic variants in multiple Loci on the risk of coronary artery disease in chinese han subjects. Circ J 2012, 76(8):1987-1992.

12. Virani SS, Brautbar A, Lee W, MacArthur E, Morrison AC, Grove ML, Nambi V, Frazier L, Wilson JM, Willerson JT, Boerwinkle E, Ballantyne CM: Chromosome 9p21 single nucleotide polymorphisms are not associated with recurrent myocardial infarction in patients with established coronary artery disease. Circ J 2012, 76(4):950-956.

13. Takeuchi F, Isono M, Nabika T, Katsuya T, Sugiyama T, Yamaguchi S, Kobayashi S, Ogihara T, Yamori Y, Fujioka A, Kato N: Confirmation of ALDH2 as a Major locus of drinking behavior and of its variants regulating multiple metabolic phenotypes in a Japanese population. Circ J 2011, 75(4):911-918.

14. Imaizumi S, Navab M, Morgantini C, Charles-Schoeman C, Su F, Gao F, Kwon M, Ganapathy E, Meriwether D, Farias-Eisner R, Fogelman AM, Reddy ST: Dysfunctional high-density lipoprotein and the potential of apolipoprotein A-1 mimetic peptides to normalize the composition and function of lipoproteins. Circ J 2011, 75(7):1533-1538.

15. Kathiresan S, Melander O, Guiducci C, Surti A, Burtt NP, Rieder MJ, et al: Six new loci associated with blood low-density lipoprotein cholesterol, highdensity lipoprotein cholesterol or triglycerides in humans. Nat Genet 2008, 40:89-197.

16. Kathiresan S, Willer CJ, Peloso GM, Demissie S, Musunuru K, Schadt EE, et al: Common variants at 30 loci contribute to polygenic dyslipidemia. Nat Genet 2009, 41:56-65.

17. Willer CJ, Sanna S, Jackson AU, Scuteri A, Bonnycastle LL, Clarke R, et al: Newly identified loci that influence lipid concentrations and risk of coronary artery disease. Nat Genet 2008, 40:161-169.

18. Gao Y, Walder K, Sunderland T, Kantham L, Feng HC, Quick M, et al: Elevation in Tanis expression alters glucose metabolism and insulin sensitivity in H4IIE cells. Diabetes 2003, 52(4):929-934.

19. Walder K, Kantham L, McMillan JS, Trevaskis J, Kerr L, De Silva A, et al: Tanis: a link between type 2 diabetes and inflammation? Diabetes 2002, 51(6):1859-1866.

20. Xie X, Ma YT, Yang YN, Fu ZY, Li XM, Huang D, et al: Polymorphisms in the SAA1/2 gene are associated with carotid intima media thickness in healthy Han Chinese subjects: the Cardiovascular Risk Survey. PLoS One 2010, 5(11):e13997.

21. Xie X, Ma YT, Yang YN, Fu ZY, Li XM, Ma X, et al: Association of genetic polymorphisms of serum amyloid protein $A 1$ with plasma high density lipoproteins cholesterol. Zhonghua Yi Xue Za Zhi 2010, 90(26):1824-1826.

22. Ye Y, Shibata Y, Yun C, Ron D, Rapoport TA: A membrane protein complex mediates retro-translocation from the ER lumen into the cytosol. Nature 2004, 429:841-847.

23. Curran JE, Jowett JB, Elliott KS, Gao Y, Gluschenko K, Wang J, et al: Genetic variation in selenoprotein $\mathrm{S}$ influences inflammatory response. Nat Genet 2005, 37:1234-1241.

24. Alanne M, Kristiansson K, Auro K: Variation in the selenoprotein S gene locus is associated with coronary heart disease and ischemic stroke in two independent Finnish cohorts. Hum Genet 2007, 122:355-365.

25. Olsson M, Olsson B, Jacobson P, Thelle DS, Björkegren J, Walley A, et al: Expression of the selenoprotein $S$ (SELS) gene in subcutaneous adipose 
tissue and SELS genotype are associated with metabolic risk factors. Metabolism 2011, 60(1):114-120.

26. Delgado-Lista J, Garcia-Rios A, Perez-Martinez P, Solivera J, Yubero-Serrano EM, Fuentes F, Parnell LD, Shen J, Gomez P, Jimenez-Gomez Y, Gomez-Luna MJ, Marin C, Belisle SE, Rodriguez-Cantalejo F, Meydani SN, Ordovas JM, Perez-Jimenez F, Lopez-Miranda J: Interleukin 1B variant -1473G/C (rs1143623) influences triglyceride and interleukin 6 metabolism. J Clin Endocrinol Metab 2011, 6(5):E816-E820.

27. Xie X, Ma YT, Yang YN, Li XM, Liu F, Huang D, et al: Alcohol consumption and ankle-to-brachial index: results from the Cardiovascular Risk Survey. PLoS One 2010, 5(12):e15181.

28. Xie X, Ma YT, Yang YN, Fu ZY, Li XM, Zheng YY, et al: Polymorphisms in the SAA1 gene are associated with ankle-to-brachial index in Han Chinese healthy subjects. Blood Press 2011, 20(4):232-238.

29. Yang Y-N, Xie X, Ma Y-T, Li X-M, Fu Z-Y, et al: Type 2 Diabetes in Xinjiang Uygur Autonomous Region, China. PLoS One 2012, 7(4):e35270.

30. Xie X, Ma YT, Yang YN, Fu ZY, Ma X, Huang D, et al: Alcohol consumption and carotid atherosclerosis in China: the Cardiovascular Risk Survey. Eur J Prev Cardiol 2012, 19(3):314-321.

31. Xie X, Ma YT, Yang YN, Fu ZY, Li XM, Huang D, et al: Interaction between COX-2 G-765C and smoking in relation to coronary artery disease in a Chinese Uighur population. Clin Chem Lab Med 2011, 49(1):55-60.

doi:10.1186/1476-511X-12-97

Cite this article as: Gao et al: Genetic variation in Tanis was associated with elevating plasma triglyceride level in Chinese nondiabetic subjects. Lipids in Health and Disease 2013 12:97.

\section{Submit your next manuscript to BioMed Central and take full advantage of:}

- Convenient online submission

- Thorough peer review

- No space constraints or color figure charges

- Immediate publication on acceptance

- Inclusion in PubMed, CAS, Scopus and Google Scholar

- Research which is freely available for redistribution 